\title{
SiM
}

\section{Restoring Mixed Grass Prairie in Southeastern Alberta, Canada}

\author{
By Brad A. Downey, Francois Blouin, Jennifer D. Richman, Brandy L. Downey, \\ and Paul F. Jones
}

\section{On the Ground}

- Between 2008 and 2010 a cultivated field of 57 ha within the mixed grass prairie of southeastern Alberta was restored with native grasses and silver sagebrush plugs.

- Wildlife occupying the site increased from being dominated by horned larks to 13 species using the land within 3 years. Two of these species Sprague's pipit and chestnut-collared longspur are native grassland specialists considered "Threatened" under Canada's Species at Risk Act.

- Litter values on the reseed in year 3 were approaching normal values that would be expected on a loamy site within a healthy mixed grass prairie.

Keywords: sagebrush, seed sowing, species at risk, Sprague's pipit.

Rangelands 35(3):16-20

doi: 10.2111/RANGELANDS-D-12-00082.1

(C) 2013 The Society for Range Management

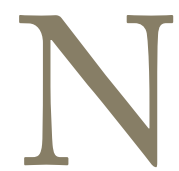

ative grasslands have evolved over thousands of years and comprise a variety of grass, forb, and shrub species, each of which plays a role in community composition. However, over the last 90 years we have lost roughly $80 \%$ of our native grasslands in Canada and $70 \%$ of our grasslands across the Northern Great Plains of North America. ${ }^{1,2}$ Native grass restoration efforts are occurring throughout North America and the rest of the world as a means to increase biodiversity and natural landscapes. ${ }^{3}$ Conversion of abandoned cropland to native grass is a key area for restoration, with several efforts and successes throughout North America resulting from sowing seeds., The diversity in structure and plant composition with native grasslands is important to the nesting, rearing, and foraging of wildlife, including species at risk such as Sprague's pipit (Anthus spragueii) and chestnut-collared longspur (Calcarius ornatus). 6,7 "Species at risk" is a term referring to all species listed as "endangered," "threatened," or "species of special concern" under Canada's Species at Risk Act.

Native grasslands and many of the associated wildlife species have declined significantly across the Northern Great Plains., ${ }^{8,9}$ In Alberta only $43 \%$ of the driest portion of the mixed grass prairie remain, and these remaining areas are subjected to ongoing fragmentation and human development. ${ }^{9,10}$ Loss of native grasslands, whether large or small scale, have direct negative impacts on wildlife with specialist needs provided by grassland systems. These cultivated areas within large contiguous grassland blocks are areas largely devoid of wildlife specialists and provide a foothold for invasive plant species to establish and spread to adjacent native grassland and modify habitat that has taken thousands of years to evolve. Efforts to restore these "gaps" with grass, forb, and shrub species found in the local native plant community can help reverse this degradation, improving their value to wildlife, including species at risk, and at the same time also be effective in providing additional grazing opportunities for landowners. These restoration efforts can be expensive even using low diversity mixtures (\$243-\$720/ha; all dollar amounts in this paper given in Canadian dollars), which solidifies the need to maintain our existing native grasslands. ${ }^{3}$

\section{The Right Mix}

Restoration efforts have changed over the decades. Early approaches focused on establishing perennial cover. These were predominantly tame pasture or hay lands comprising agronomic species or a mix of native and non-native grass. Where these initiatives provided habitat for some common grassland bird species (generalists) they provided little benefit to habitat specialists, many of which are now listed as species at risk. ${ }^{11,12,13}$ Planted grasslands comprised of nonindigenous species including bluegrass (Poa spp.), brome (Bromus spp.), and alfalfa (Medicago sativa) were found to be sink habitat for specialized avian fauna such as Sprague's pipit. ${ }^{13}$ More recently, the approach of using native species to reclaim the land to a state that mimics that site's natural community is occurring. This switch to restoration of native grasses is im- 
portant, but even in these cases the correct native grass mixture for a specific ecological range site are not usually chosen, as limited resources favors selection of cheaper varieties, which negates the efforts to restore species that are dominant in the native reference plant community.

In 2008 MULTISAR, a project managed by Alberta Conservation Association (ACA), Alberta Environment and Sustainable Resource Development (ESRD), and the Prairie Conservation Forum (PCF), collaborated with a private landowner to restore 57 ha of native grasslands, using a seed mixture matching the local native plant community that would be expected to occur on that target site. We evaluated two aspects of the restoration from before seeding to 3 years after 1) change in the vegetation composition found on the site and 2) change in the wildlife species richness on the site.

\section{Understanding What Was Once There}

The 57-ha restoration project is located near Manyberries in southeastern Alberta within the dry-mixedgrass (mixed grass prairie) natural subregion. The site is a "U"-shaped parcel of land surrounded by native grassland and occurs on the edge of a large parcel of native grassland to the south, and a mixture of cropland and grassland to the north. Loamy soils are found on the site, which was previously used as cropland that switched between chemical fallow and crop every other year since 2003.

Plant communities on loamy soils identified in the "Range Plant Communities and Range Health Assessment Guidelines for the Dry Mixedgrass Natural Subregion of Alberta" include needle and thread (Hesperostipa comata), blue grama grass (Boutelua gracilis), June grass (Koeleria macrantha), northern and western wheatgrass (Elymus lanceolatus and Pascopyrum smithii), low sedge (Carex duriuscula), sandberg bluegrass (Poa secunda ssp.secunda), silver sagebrush (Artemisia cana), pasture sagewort (Artemisia frigida), and scarlet mallow (Sphaeralcea coccinea). ${ }^{10}$ Species at risk observed in these native plant communities include Sprague's pipit, chestnutcollared longspur, and long-billed curlew (Numenius americanus). Total precipitation for the area is $353 \mathrm{~mm}$ with the majority of precipitation (209 $\mathrm{mm}$ ) occurring between May and September.

A range inventory was completed in the adjacent native grassland in 2007 prior to restoration to identify the plant community and its species composition. A 50-m transect was defined at a representative site within the community and a Daubenmire frame was placed at 5-m intervals to record the percentage foliar cover of each species. Each species was averaged over the 10 frames of each transect to determine species composition. ${ }^{14}$

\section{Starting the Process}

In 2008 the site was prepared for seeding by completing a preburn using glyphosate. This was done in early May to help remove unwanted weeds and grass and to ensure a clean bed in which to broadcast the seed mixture (Fig. 1). A transect

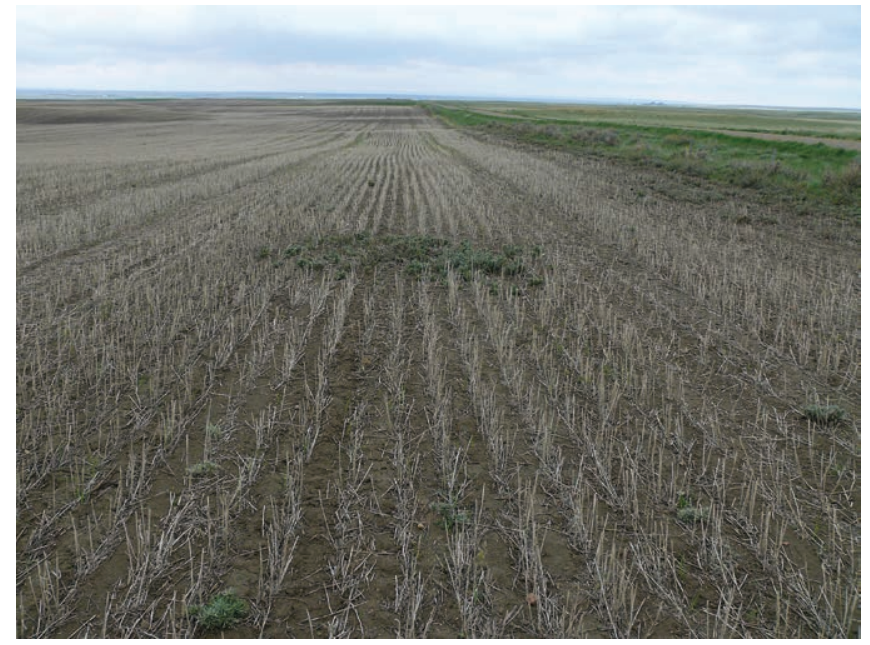

Figure 1. Year 2: following glyphosate application.

was completed in the adjacent native grassland that contained similar range sites (i.e., loamy) as the reseeded site. Based on that inventory a species mixture comprising $27 \%$ northern wheatgrass, $20 \%$ western wheatgrass, $20 \%$ blue grama grass, $17 \%$ needle and thread, and $16 \%$ June grass was chosen (based on weight). Needle and thread made up 30\% of the species composition in the native communities. Unfortunately, due to the high cost for the needle and thread seed $(\$ 110-\$ 154 / \mathrm{kg})$, resulting from increased processing costs associated with debearding, it was reduced to $17 \%$ in the seed mixture but still accounted for $50 \%$ of the final seed cost. Final cost for the seed mixture was $\$ 405 / \mathrm{ha}$, similar to what was identified in Europe for a low-diversity seed mixture. ${ }^{3}$

Broadcast seeding was selected over direct seeding due to potential clogging of the hoses on the seed drill, wet conditions that favored broadcast seeding, increased survivorship, and the desire to create heterogenic habitat. ${ }^{4,5}$ Native grass seed was broadcast at $10 \mathrm{~kg} / \mathrm{ha}$ using a broadcast seeder behind a tractor and followed up with a light harrow to ensure good soil to seed contact. A fence was installed around the property to prevent disturbance and to let the grass establish. In August 2008, the site was mowed and baled to reduce Russian thistle (Salsola kali) and kochia (Kochia scoparia), which had established during the summer. We assessed the site in summer 2008 to determine if the seeded grass was establishing on the site.

Target broadleaf herbicide was sprayed in spring 2009 to combat Russian thistle and kochia (Fig. 2). One hundred and fifty silver sagebrush plugs were planted in low-lying areas 2 weeks after spraying to add a natural shrub component to the newly established community. Sagebrush plugs were 7.5 $\mathrm{cm}$ tall with an additional $10 \mathrm{~cm}$ of root mass. Plugs were inserted into the ground by hand using a metal pole to create the hole, placing the plugs in the ground, and compacting the soil around them. Detailed range transects and range health assessments were conducted in 2010. We completed range health assessments to measure ecological integrity, litter, 


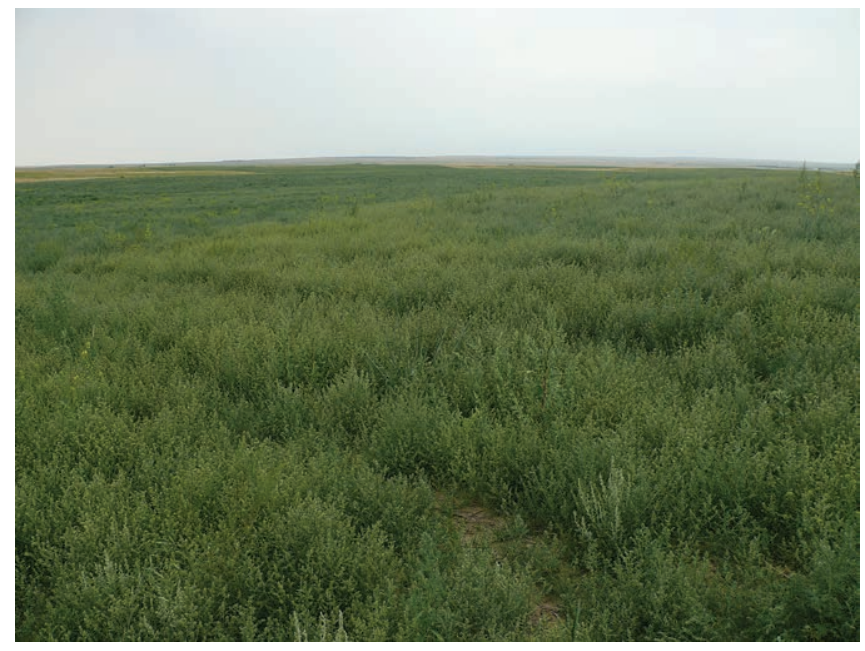

Figure 2. Year 1: thistle and kochia on the site.

structure, weeds, and bare soil. ${ }^{15}$ Ecological integrity looked at how well the community resembles a reference community that would normally be found on the site. Litter values that measure the past year's growth were determined by raking one plot frame $\left(0.25 \mathrm{~m}^{2}\right)$ and estimating the amount of litter $(\mathrm{kg} / \mathrm{ha})$. Structure was assessed to determine if all four layers were present: 1) low shrubs, 2) tall graminoids and forbs, 3) medium graminoids and forbs, and 4 ) ground cover. ${ }^{15}$ Weeds and bare ground looked at the number and density of invasive plants and how much of the bare ground was human caused. ${ }^{15}$ Range health scores were determined by adding up each of the five factors.

We conducted point counts for wildlife at four sites within the reseeded area and one control site in the adjacent native grassland in June 2007, 2009, and 2010. We recorded all birds, mammals, and herptiles seen or heard within a $100 \mathrm{~m}$ radius over a 5-minute period at each site in each year.

\section{Creating Habitat Requires Patience and Precipitation}

Precipitation amounts in 2008, totaling $209 \mathrm{~mm}$ between May and September, matched the long-term average for the area. Site evaluation in September 2008 (first growing season) revealed the presence of all five planted grass species on the site. Native wheatgrasses made up $9.6 \%$ of the vegetative composition, followed by blue grama (4\%), June grass ( $0.5 \%)$, and needle and thread (trace). In 2009 precipitation amounts were lower than average $(188 \mathrm{~mm})$, and Russian thistle and kochia were decreasing in cover, providing opportunities for the native grass seedlings. In 2010 precipitation was above average $(240 \mathrm{~mm})$, and the establishing plant community contained $13.4 \%$ blue grama, $13 \%$ northern wheatgrass, $10.9 \%$ June grass, $6.7 \%$ western wheatgrass, $4.7 \%$ needle and thread grass, $2.8 \%$ green needle grass (Nassella viridula), $2.8 \%$ pasture sage (Artemisia frigida), and $26 \%$ bare soil (Fig. 3). Litter values ranged between $179 \mathrm{~kg} / \mathrm{h}$ and $280 \mathrm{~kg} / \mathrm{ha}$ with the average range health score being $69 \%$ (healthy with prob-

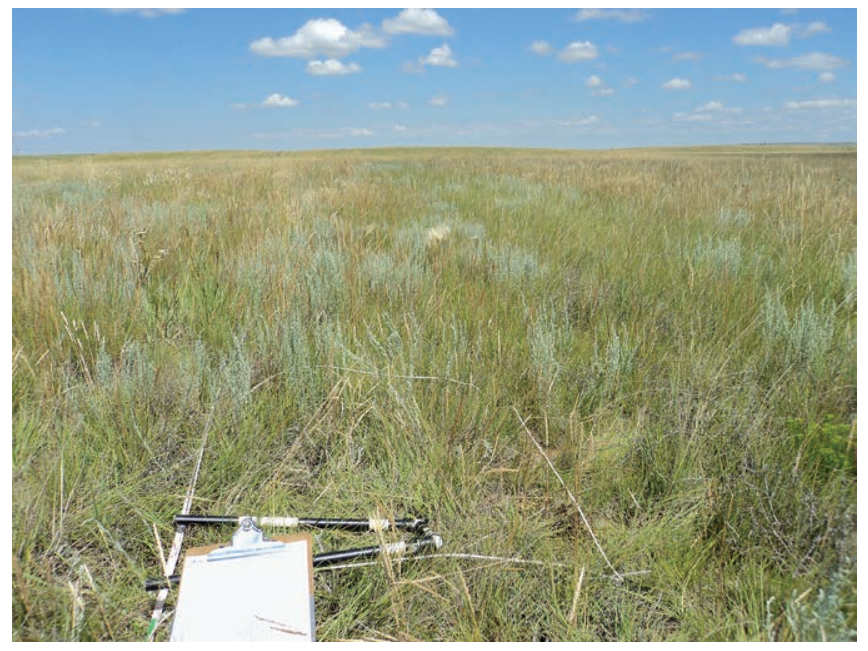

Figure 3. Year 3: establishing grassland.

lems). Litter amounts equaling or exceeding $291 \mathrm{~kg} / \mathrm{ha}$ are considered excellent for the mixed grass prairie. ${ }^{14}$ All silver sagebrush plugs planted (100\%) in 2009 had established, and the young shrubs were branching out and increasing in height in 2010.

\section{A New Home}

Wildlife surveys on the reseeded site conducted in June 2007 (preseeding) identified a landscape dominated by horned larks (Eremophila alpestris), with McCown's longspurs (Calcarius mccownii) heard on the periphery next to native grasslands. The native control site had eight species present in 2007 including chestnut-collared longspurs; however, no Sprague's pipits were heard. Wildlife point count surveys completed in June 2009 revealed seven species utilizing the reseeded area and nine species on the native control. Baird's sparrow ( $\mathrm{Am}$ modramus bairdii), western meadowlark (Sturnella neglecta), and vesper sparrow (Pooecetes gramineus) were all found on both the control and reseeded area. Chestnut-collared longspur was again found only on the native control site. In June 2010 wildlife point counts identified 13 species at point count stations using the reseeded site and 12 using the native site (Fig. 4). The increase in species as well at the control site may be related to its proximity to the restoration site and the impact of filling in the "gap," thereby reducing fragmentation. Sprague's pipit and chestnut-collared longspurs were identified on both the reseeded and native control sites. Other species found on the reseeded site but not on the native control included sharp-tailed grouse (Tympanuchus phasianellus) and grasshopper sparrow (Ammodramus savannarum).

\section{Why Native Grass Is Important for Wildlife}

Native grasslands contain a high plant species diversity and heterogenic structure not found in most tame pastures, which are characterized as having a few species in a homogenous structure. Plant species diversity and heterogeneity in vertical and horizontal structure are important characteristics 


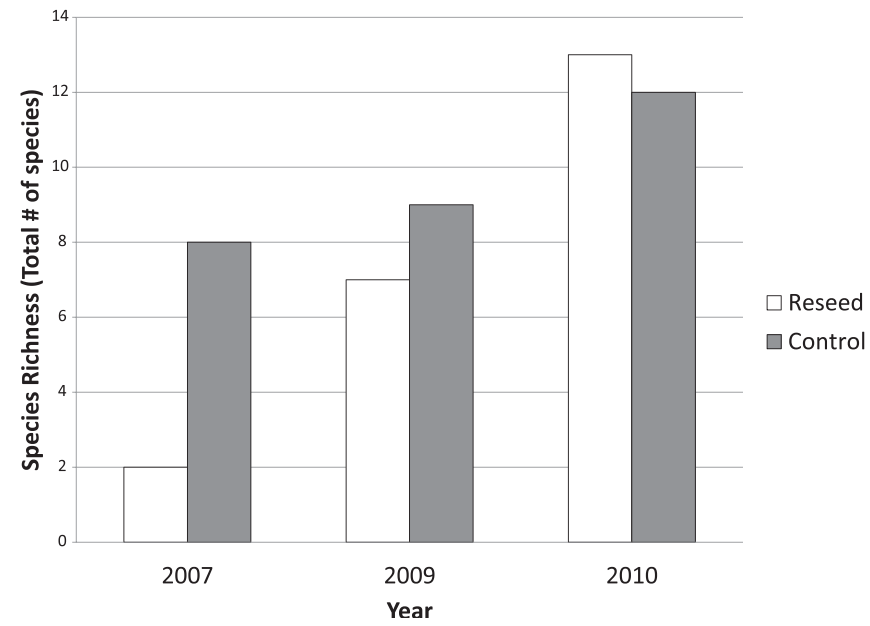

Figure 4. Change in species richness over time at reseeded and native control sites.

to consider when creating habitat for native wildlife species including several species at risk.

Native grassland restoration projects need to consider matching the species used in the seed mix with what would be expected in native habitats on similar soil types. This requires looking at the soils and plant communities in adjacent land and selecting a seed mixture based on what would be the dominant plant community for that soil type. In this project using this process, wildlife species richness (number of species) on the site was increased from two to 13 species in 3 years. Two species at risk were present on the site by year 3, providing evidence that native grass restoration efforts can create suitable habitat for these species.

\section{The Next Phase}

Only native grasses were seeded. This allowed for spraying for broadleaf weeds in year 2 without loss of seeded forbs due to chemical treatment of the site. Chemical treatment was used once in the spring as the majority of the site contained Russian thistle and kochia. This gave the native grasses a competitive edge, and they outcompeted the weeds. As with several plant communities in the mixed grass prairie, forbs make up a component of the community and should be considered in year 2 or 3 after broadleaf control has been completed. For this small study site, natural colonization of forbs was monitored. An influx of desirable forbs was observed including pasture sagewort (Artemisia frigida) and western yarrow (Achillea millefolium), which do well in more disturbed landscapes. Future restoration projects will include a forb component compatible with the surrounding native community in year 2 or 3 . Sagebrush plugs planted on the site developed extremely well and should be used in future restoration efforts.

Limitations exist in relation to seed cost and availability, but using species that would normally dominate the plant community can help restore the native habitats. Success in restoration is dependent on precipitation and location but also on seed selection. It is therefore important to know the characteristics of the site well ahead of time and select a compatible seed mixture.

\section{Good for Cattle and Wildlife}

Restoration activities using native grasses specifically suited to an area can be beneficial to a ranching operation by increasing grazing opportunities and at the same time create habitat for species at risk. Further research is needed at this site and others to compare seeded native grass versus naturally occurring native grasslands in relation to use by wildlife. Research should focus on breeding success of rare species of grassland birds such as Sprague's pipit and chestnut-collared longspur. Native grassland restoration efforts should focus on wildlife habitat creation for rare species and match plant communities based on ecological site characteristics and the needs of those species.

\section{Acknowledgements}

We would like to thank the landowner and land manager of J Bar J Ranch for their desire to reseed native grass, continued collaboration with the MULTISAR Program, and implementation of the project through reseeding activities and fence installation. Danielle Cross (ESRD) was instrumental in developing the planned restoration project on the 57 ha. We also thank Marilyn Neville, Morgan Stromsmoe, and Craig Demaere for their time taken to answer questions and be consulted with about the project, Terry Hood (ESRD) for assisting with the range assessments, and the MULTISAR staff and consultants who completed the range and wildlife surveys from 2007-2010 on the J Bar J Ranch: Danielle Cross, Darryl Jarina (PCF), Kristen Rumbolt-Miller (PCF), Carla Koenig (ACA), Lee Moltzahn (ACA), Maria Didkowsky (ACA), Sophie LaRocque (ACA), Chad Lyttle (ACA), Christy Sikina (ESRD), Kristine Dahl (ACA), Joel Nicholson (ESRD), and Varge Craig (Consultant). Thank you to Doug Manzer (ACA), Lance Engley (ACA), Richard Quinlan (ESRD), and Kevin France (ESRD) for reviewing an earlier draft of this manuscript.

\section{References}

1. Bailey, A., D. McCartney, and M. Schellenberg. 2010. Management of Canadian prairie rangeland. Swift Current, SK, Canada: Agriculture and Agri-Food Canada, Government of Canada. 58 p.

2. Samson, F. B., F. L. Knopf, and W. R. Ostlie. 2004. Great Plains ecosystems: past, present, and future. Wildlife Society Bulletin 32(1):6-15.

3. Török, P., E. Vida, B. DeÁk, S. Lengyel, and B. Tóthmérész. 2011. Grassland restoration on former croplands in Europe: an assessment of applicability of techniques and costs. Biodiversity and Conservation 20:2311-2332.

4. Bakker, J. D., S. D. Wilson, J. M. Christian, X. Li, L. G. Ambrose, And J. Waddington. 2003. Contingency of grassland restoration on year, site, and competition from introduced grasses. Ecological Applications 13:137-153. 
5. Foster, B. L., C. A. Murphy, K. R. Keller, T. A. AschenBACH, E. J. Questad, AND K. Kindscher. 2007. Restoration of prairie community structure and ecosystem function in an abandoned hayfield: a sowing experiment. Restoration Ecology 15:652-661.

6. COSEWIC. 2009. COSEWIC assessment and status report on the chestnut-collared longspur (Calcarius ornatus) in Canada. Ottawa, ON, Canada: Committee on the Status of Endangered Wildlife in Canada. Available at: http://www.sararegistry.gc.ca/ document/default_e.cfm?documentID=1977. Accessed 17 February 2012.

7. Environment Canada. 2008. Recovery strategy for the Sprague's pipit (Anthus spragueii) in Canada. Species at Risk Act Recovery Strategy Series. Ottawa, ON, Canada: Environment Canada. 29 p.

8. Gauthier, D. A., And E. B. Wiken. 2003. Monitoring the conservation of grassland habitats, prairie ecozone, Canada. Environmental Monitoring and Assessment 88:343-364.

9. Saunders, E., R. Quinlan, P. Jones, B. Adams, and K. Pearson. 2006. At home on the range: living with Alberta's prairie species at risk. Lethbridge, AB, Canada: Alberta Conservation Association and Alberta Sustainable Resource Development. $47 \mathrm{p}$.

10. Adams, B. W., L. Poulin-Klein, D. Moisey, and R. L. McNeIL. 2005. Rangeland plant communities and range health assessment guidelines for the dry mixedgrass natural subregion of Alberta. Lethbridge, AB, Canada: Rangeland Management Branch, Public Lands Division, Alberta Sustainable Resource Development. Publication No. T/040. 106 pp.

11. McMaster, G. D., J. H. Devries, and S. K. Davis. 2005. Grassland birds nesting in haylands of southern Saskatchewan: landscape influences and conservation priorities. Journal of Wildlife Management 69:211-221.
12. Kennedy, P. L., S. J. DeBano, A. M. Bartuszevige, and A. S. LUEDERS. 2008. Effects of native and non-native grassland plant communities on breeding passerine birds: implications for restoration of northwest bunchgrass prairie. Research Ecology 17:515-525.

13. Fisher, R. J., and S. K. Davis. 2011. Post-fledging dispersal, habitat use, and survival of Sprague's pipits: are planted grasslands a good substitute for native? Biological Conservation 144:263-271.

14. Willoughby, M. G. 2007. Range survey manual for Alberta rangelands. Version one. Edmonton, AB, Canada: Rangeland Management Branch, Alberta Sustainable Resource Development. Publication No. I/176. 124 p.

15. Adams, B. W., R. Ehlert, C. Stone, M. Alexander, D. LaWrence, M. Willoughby, D. Moisey, C. Hincz, A. Burkinshaw, J. Carlson, and K. France. 2009. Range health assessment for grassland, forest and tame pasture. Lethbridge, $A B$, Canada: Public Lands and Forest Division, Alberta Sustainable Resource Development. Publication No. T/044. 128 pp.

Authors are Wildlife Biologists (Brad Downey, Brad.Downey@ abconservation.com, and Jones), Alberta Conservation Association, Lethbridge, AB T1J OP3, Canada; Wildlife Biologist, Prairie Conservation Forum, Lethbridge, AB T1J 4L1, Canada (Blouin); Range Management Specialist (Richman) and Wildlife Biologist (Brandy Downey), Alberta Environmental and Sustainable Resource Development, Edmonton, AB T5K 2M4, Canada. Restoration and monitoring was funded by Environment Canada's Habitat Stewardship Program for Species at Risk, Canadian Natural Resources Limited, Alberta Conservation Association, Innovation Alberta, and Environment and Sustainable Resource Development through a grant to the Prairie Conservation Forum. 